\title{
Climate-smart livestock production: options for Nigerian farmers
}

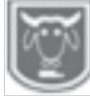

Abstract
Iyiola-Tunji, A. O.

National Agricultural Extension and Research Liaison Services, A hmadu Bello University, Zaria

This paper is focused on reviewing the three key pillars of climate-smart agriculture (CSA) in relation to livestock production (i.e., increased productivity, mitigation of greenhouse gases emissions and adaptation to climate change) while exploring the development intervention options for Nigerian livestock farmers. The most serious impacts of climate change are anticipated in grazing systems because of their dependence on climatic conditions and the natural resource base, and their limited adaptation opportunities. Impacts are expected to be most severe in arid and semi-arid grazing systems at low latitudes, where higher temperatures and lower rainfall are expected to reduce yields on range lands and increase land degradation. The dual pathways of responses between climate change and livestock production activities were depicted in this review. It is of note that climate change as a natural phenomenon works on the principle of causes and effect. The actions and in-actions of man will dictate the type of results obtainable in his immediate environment. Means by which livestock farmers can mitigate the GHGs and adapt to the effect of climate changes were discussed in this paper. Concerted efforts at ameliorating the effect of climate change on livestock production are needed. The smart options for rearing livestock are capable of mitigating the attendant effect of production activities of the stocks, reducing the stress obtainable from altered environment and ensuring food security. Nigeria as a country will need to evolve policies that will ensure promotion and subsequent adoptions of technologies that are smart in terms of increasing productivity of farm animals, reducing emissions of GHG and positivelyaltering the effect of climate change.

Keywords: Climate-smart agriculture, Livestock, adaptation to climate, mitigation, farmers

\section{Production animale climato-intelligente: options pour les agriculteurs nigérians}

\section{Résumé}

Cet article se concentre sur l'examen des trois piliers clés de l'agriculture intelligente face au climat (ASC) en relation avec la production animale (c.-à-d. Augmentation de la productivité, atténuation des émissions de gaz à effet de serre et adaptation au changement climatique) tout en explorant les options d'intervention de développement pour les éleveurs nigérians. Les impacts les plus graves du changement climatique sont anticipés dans les systèmes de pâturage en raison de leur dépendance aux conditions climatiques et de la base de ressources naturelles, et de leurs possibilités d'adaptation limitées. Les impacts devraient être les plus graves dans les systèmes de pâturage arides et semi-arides à basses latitudes, où des températures plus élevées et des précipitations plus faibles devraient réduire les rendements sur les pâturages et augmenter la dégradation des terres. Les doubles voies de réponses entre le changement climatique et les activités de production animale ont été décrites dans cette revue. Il est à noter que le changement climatique en tant que phénomène naturel fonctionne sur le principe des causes et des effets. Les actions et les in-actions de 
l'homme dicteront le type de résultats pouvant être obtenus dans son environnement immédiat. Les moyens par lesquels les éleveurs peuvent atténuer les GES et s'adapter aux effets des changements climatiques ont été discutés dans ce document. Des efforts concertés pour atténuer les effets $d u$ changement climatique sur la production animale sont nécessaires. Les options intelligentes pour l'élevage du bétail sont capables d'atténuer l'effet connexe des activités de production des stocks, de réduire le stress résultant de l'altération de l'environnement et d'assurer la sécurité alimentaire. Le Nigéria, en tant que pays, devra élaborer des politiques qui assureront la promotion et l'adoption ultérieure de technologies intelligentes en termes d'augmentation de la productivité des animaux d'élevage, de réduction des émissions de GES et de modification positive des effets du changement climatique.

Mots clés: agriculture climato-intelligente, élevage, adaptation au climat, atténuation, agriculteurs

\section{Introduction}

Climate change impacts agriculture through a number of pathways. According to the

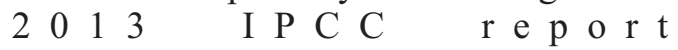
(https://www.ipcc.ch/report/ar5/wg1/), all four dimensions of food security are potentially affected by climate change through their effects on agricultural production and the incomes of rural households, food prices and markets, and in many other parts of the food system (e.g., storage, food quality and safety) (Revi et $a l .$, 2014). Reducing the vulnerability of agricultural systems to climate change including the increased incidence of extreme weather events - and strengthening its adaptive capacity are therefore, important priorities to protect and improve the livelihoods of the poor and allow agriculture to fully play its role in ensuring food security. Reducing emissions that contribute to global warming is crucial to securing global wellbeing, and agricultural sector has considerable potential for emissions reduction while at the same time playing its important role in poverty reduction and food security. In short, agriculture lies at the nexus of resolving urgent global priorities. The Food and Agriculture Organization (FAO) is actively working to support countries in grappling with the challenge of managing agriculture to reduce hunger and poverty in an increasingly climate constrained world. FAO launched the concept of climate-smart agriculture (CSA) in 2009 to draw attention to linkages between achieving food security and combating climate change through agricultural development, and the opportunities for attaining large synergies in doing so. In practice, the CSA approach involves integrating the need for adaptation and the potential for mitigation into the planning and implementation of agricultural policies, planning, and investments. The point of departure for the CSA approach is the emphasis on food security and poverty reduction. Livestock makes a key contribution to global food security. Its contribution is especially important in marginal lands where livestock represents a unique source of energy, protein and micronutrients. Climate change has substantial impacts on ecosystems and the natural resources upon which the livestock sector depends. At the same time, livestock food chains are major contributors to greenhouse gas emissions (FAO, 2006). Livestock production is a rapidly growing sector. It accounts for 40 percent of the global agricultural gross domestic product and is crucial for food security in all regions. In sub-Saharan Africa, more than half the population keep livestock, and one in three of these livestock keepers can be considered poor (FAO, 2012). This paper is focused on reviewing the three key pillars of CSA in 


\section{Iyiola-Tunji}

relation to livestock production (i.e., increased productivity, mitigation of greenhouse gases emissions and adaptation to climate change) while exploring the development intervention options for Nigerian livestock farmers.

\section{Impact of climate change on livestock production}

The most serious impacts of climate change are anticipated in grazing systems because of their dependence on climatic conditions and the natural resource base, and their limited adaptation opportunities (Aydinalp and Cresser, 2008). Impacts are expected to be most severe in arid and semi-arid grazing systems at low latitudes, where higher temperatures and lower rainfall are expected to reduce yields on range lands and increase land degradation (Hoffmann and Vogel, 2008). The direct impacts of climate change are likely to be more limited in non-grazing systems mostly because the housing of animals in buildings allows for greater control of production conditions (FAO, 2009; Thornton and Gerber, 2010). Indirect impacts will be experienced through modifications in ecosystems, changes in the yields, quality, type and availability of feed and fodder crops, and greater competition for resources with other sectors (FAO, 2009; Thornton, 2010; Thornton and Gerber, 2010). Climate change could lead to additional indirect impacts from the increased emergence of livestock diseases, as higher temperatures and changed rainfall patterns can alter the abundance, distribution and transmission of animal pathogens (Baylis and Githeko, 2006). In non-grazing systems, indirect impacts from lower crop yields, feed scarcity and higher feed and energy prices will be more significant. Climate change, in particular global warming, likely affects animal health by influencing the hostpathogen-environment system both directly and indirectly. The direct effects are more likely to influence diseases that are associated with vector transmission, water or flood, soil, rodents, or air temperature and humidity (Abdela and Jilo, 2016). Indirect impacts of climate change are more complex to disentangle and include those deriving from changes in land use and biodiversity and the attempt of animals to adapt to these climatic and environmental changes or from the influence of climate on microbial populations, distribution of vector-borne diseases and host resistance to infectious agents, feed and water scarcity, or food-borne diseases.

Species-specific strategies for adaptation and mitigation of climate change Small and large ruminants

Addressing climate change will involve rearing animals that are robust, more heat tolerant, more disease resistant, and are relatively adaptable to the difficult conditions. Small ruminants contribute enormously towards the promotion of livelihood security and as an insurance to cope with crop failure, particularly for rural, small and marginal farmers (Pasha, 2000; Misra, 2005). It is common among families to rear one to three sheep or goats. Also, goat farming is increasingly being taken up by the peri-urban poor population owing to easy market access and as a source of nutritional security for the household (Pollot and Wilson, 2009). Although small ruminants are often cited for negatively impacting on the environment, they can improve soil and vegetation cover. By consuming biomass, which otherwise might provide the fuel for bush fires, by controlling shrub growth and by dispersing seeds through their hooves and manure, small ruminants can contribute to plant biodiversity. Trampling can stimulate grass tilling, advance seed germination, and break up hard soil crusts (Steinfeld et al., 2006). If farmers can adopt early adaptations, they can reduce the effect from climate change, because adaptations are efforts to produce low-emission grazing 


\section{Climate-smart livestock production: options for Nigerian farmers}

systems and more sustainable rangeland management (Harle et al., 2007). In contrast to sheep and cattle that avoid bush thickets, browsing goats prune and inhibit bush growth that in turn will advance the growth of grasses. With the right management and grazing controls, a goat industry could be a useful tool for sound rangeland management. Grazing by goats can provide biological weed control. Biological control is a more environmentally acceptable form than certain other methods of control. Grazing treatments can be applied to difficult terrain where access is limited. However, attention must be paid to adequate fencing. Grazing can provide continuous, therefore more effective pressure on numerous weeds that have staggered or delayed germination cycles. Clovers are least favored. Therefore, while weeds are being grazed out, the more valuable clovers build up. Goats can be run with sheep and cattle. Their grazing is complementary to both. So, goats can be added to sheep or cattle herds with little loss in production of the sheep or cattle.

\section{Monogastric animals}

Poultry meat and egg production are the most efficient animal protein production systems. Poultry meat production is the most environmentally efficient (smallest carbon footprint per unit product produced), followed by pork and mutton (primarily lamb) with beef the least efficient (Williams et al., 2006). This results from several factors, including the low overheads of poultry breeding stock (much greater fecundity of hens; 250 progeny per hen each year versus one calf per cow); efficient feed conversion; high daily weight gain of poultry (made possible by genetic selection and improved dietary formulation). Poultry and pigs consume high-value feeds and rely on arable land, as their nutritional needs are overwhelmingly met by arable crops. These production systems often depend to a large extent on concentrated feed. Thus, the major environmental impacts on them are associated with production outside the farm and on-farm delivery of concentrated feed (Vander Werf et al., 2005). In terms of the impact of climate change on primary energy consumed, ruminants are about $50 \%$ higher than pig or poultry meat production. However, although ruminant meat incurs more burdens than pig or poultry meat, ruminants can derive nutrition from land that is unsuitable for arable crops (Williams et al., 2006). The adoption of organic poultry production systems is not a solution. Most organic animal production reduces primary energy use by $15 \%$ to $40 \%$, but organic poultry meat and egg production increase energy use (Van der Sluis, 2007). Free-range (non-organic) poultry increases energy use for meat by $20 \%$ and for eggs by $15 \%$, compared with all-housed production. The benefits of the lower energy needs of organic feeds are over-ridden by lower bird performance. Organic poultry has a higher food conversion ratio and a longer growing period, resulting in increased energy requirement for organic poultry meat production. Organic egg production needs more energy than non-organic and increases most environmental burdens (except pesticides), but the required land area more than doubles (Vander Sluis,2007). Pork production shows a reduction of all environmental burdens from organic production, but uses considerably more land to produce feed. Finishing pigs at a heavier weight slightly reduce in burdens, mainly as a result of reducing the overheads of breeding piglets. The choice of indoor or outdoor sow housing has a negligible effect on pork production contribution to climate change (Williams et al., 2006). The bulk of greenhouse gas and ammonia (indirect source of greenhouse gas emissions) from pig production systems are from pig housing and slurry storage (Van der PeetSchwering et al., 1999). These emissions can be reduced by: lowering the 


\section{Iyiola-Tunji}

concentrations of urea and ammonia in the slurry; lowering the temperature of the slurry; reducing the emitting surface area; reducing the $\mathrm{pH}$ of the slurry.

Various housing techniques have been developed to reduce emissions. A combination of housing and feeding measures seems most promising to achieve a substantial reduction in emissions at relatively low cost (Van der Peet-Schwering etal., 1999).

Adaptive measures toward mitigation of effect of climate change on livestock

An adaptation such as the modification of production and management systems involves diversification of livestock animals and crops, integration of livestock systems with forestry and crop production and changing the timing and locations of farm operations (IFAD, 2010).

Diversification of livestock and crop varieties can increase drought and heat wave tolerance and may increase livestock production when animals are exposed to temperature and precipitation stresses. In addition, this diversity of crops and livestock animals is effective in fighting against climate change-related diseases and pest outbreaks (Kurukulasuriya and Rosenthal, 2003; Batima et al., 2005; IFAD, 2010).

Changes in breeding strategies can help animals increase their tolerance to heat stress and diseases and improve their reproduction and growth development (Rowlinson et al., 2008; Henry et al., 2012). Adjusting animal diets can also be used as a mitigation measure, by changing the volume and composition of manure. GHG emissions can be reduced by balancing dietary proteins and feed supplements. If protein intake is reduced, the nitrogen excreted by animals can also be reduced. Supplements such as tannins are also known to have the potential to reduce emissions.

Tannins are able to displace the nitrogen excretion from urine to faces to produce an overall reduction in emissions (Hess et al., 2006; Dickie et al., 2014). Some of the adaptable technologies for reducing the effect of livestock production activities on climate change and vice versa were also presented on Table 1 and discussions on each of them are presented below:

Table 1: Adaptable technologies for reducing the effect of livestock production activities on climate change

\begin{tabular}{|c|c|c|c|c|c|c|}
\hline $\begin{array}{l}\text { Adaptable } \\
\text { technologies }\end{array}$ & $\begin{array}{l}\text { Sahel } \\
\mathrm{N}=22\end{array}$ & $\begin{array}{l}\text { Sudan } \\
\mathbf{N}=\mathbf{5 7}\end{array}$ & $\begin{array}{l}\text { Northern } \\
\text { Guinea } \\
\text { Savannah } \\
\text { N=61 }\end{array}$ & $\begin{array}{l}\text { Southern } \\
\text { Guinea } \\
\text { Savannah } \\
\text { N=80 }\end{array}$ & $\begin{array}{l}\text { Derived } \\
\text { Savannah } \\
\mathrm{N}=106\end{array}$ & $\begin{array}{l}\text { Total } \\
\mathrm{N}=326\end{array}$ \\
\hline $\begin{array}{l}\text { Proper livestock health } \\
\text { management and } \\
\text { welfare }\end{array}$ & $\begin{array}{l}13 \\
(59.1)\end{array}$ & $\begin{array}{l}40 \\
(70.2)\end{array}$ & $34(55.7)$ & $55(68.8)$ & $64(60.4)$ & $206(63.2)$ \\
\hline $\begin{array}{l}\text { Adequate waste } \\
\text { management and } \\
\text { utilization }\end{array}$ & $\begin{array}{l}13 \\
(59.1)\end{array}$ & $\begin{array}{l}32 \\
(56.1)\end{array}$ & $40(65.6)$ & $43(53.8)$ & $65(61.3)$ & $193(59.2)$ \\
\hline $\begin{array}{l}\text { Crop-livestock } \\
\text { integration system }\end{array}$ & $9(40.9)$ & $\begin{array}{l}28 \\
(49.1)\end{array}$ & $32(52.5)$ & $36(45.0)$ & $59(55.7)$ & $164(50.3)$ \\
\hline $\begin{array}{l}\text { Breeding for more } \\
\text { productive animals }\end{array}$ & $\begin{array}{l}12 \\
(54.5)\end{array}$ & $\begin{array}{l}31 \\
(54.4)\end{array}$ & $28(45.9)$ & $43(53.8)$ & $49(46.2)$ & $163(5.0)$ \\
\hline $\begin{array}{l}\text { Use of methane } \\
\text { reducing feed additives }\end{array}$ & $9(40.9)$ & $\begin{array}{l}21 \\
(36.8)\end{array}$ & $21(34.4)$ & $13(16.3)$ & $22(20.8)$ & $86(26.4)$ \\
\hline Ranching & $8(36.4)$ & $\begin{array}{l}15 \\
(26.3)\end{array}$ & $18(29.5)$ & $17(21.3)$ & $26(24.5)$ & $84(25.8)$ \\
\hline
\end{tabular}

$\mathrm{N}$ is the number of respondents; Values in parenthesis are the percentages of their respective frequencies. Source: Iyiola-Tunji et al. (2021) 
Proper livestock health management and welfare

On the top of the list of technologies as dictated by the respondents $(63.2 \%)$ is proper livestock health management and welfare. Reducing greenhouse gas (GHG) emissions may seem like extra work that can hurt business, but in reality, best management practices for reducing GHG emissions can be economical (Lindgren, 2019). Animals that are maintained in optimum health conditions and given adequate welfare will have improved production efficiency and reduction of methane production from digestion of feeds.

Adequate waste management and utilization
Almost equally important technology is adequate waste management and utilization. as proposed by $59.2 \%$ of the respondents. The major contribution to greenhouse gas emissions is methane $\left(\mathrm{CH}_{4}\right)$ from ruminant animals through belching when the animals digest their feeds (Plate I). The other sources of the deleterious gases are from faecal waste excretion and storage. Adequate waste management and utilization is capable of reducing the quantity of the greenhouse gases emissions. Livestock farmers in the Sahel, Sudan and the Guinea Savannah zones of Nigeria use the faecal waste as organic fertilizers for crop production. There were occasions where the litter materials from poultry production are fed to cattle (Lamidi, 2005).

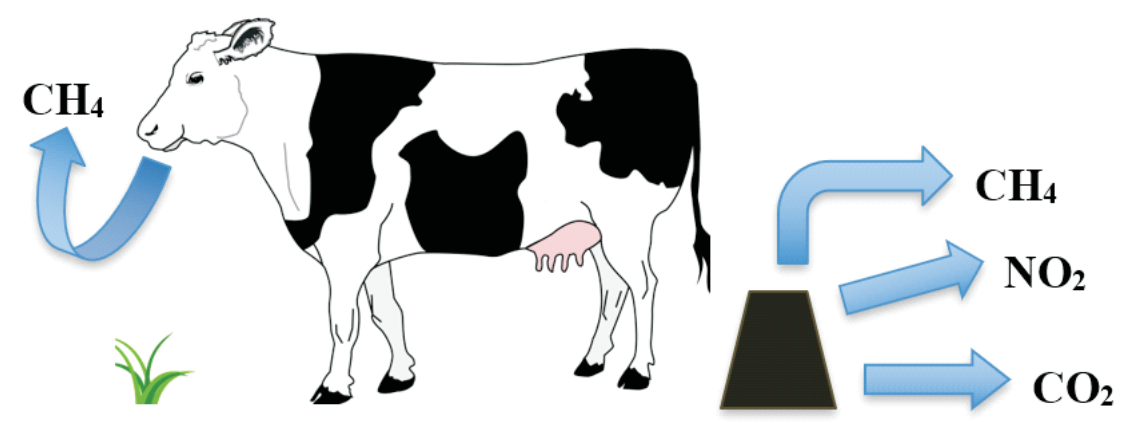

Plate I: Greenhouse gas emissions from cattle production Source: Lindgren (2019)

\section{Crop-livestock integration systems}

A lot of the effect of livestock production on climate change can be eliminated if the farmers can engage in crop-livestock integration systems. About half of the respondents $(50.3 \%)$ agreed to this fact. Ickowicz et al. (2012) presented three variants of CLIS in arid and semi-arid areas as thus: (i.) livestock only grazing systems, (ii.) rainfed mixed crop-livestock systems, and (iii.) irrigated mixed crop-livestock systems. CLIS combine cereal crops (mainly millet, cowpea, sorghum, cotton and groundnut) and majorly ruminant animal production activities in different proportions. Crop livestock integration systems (CLIS) enable recycling of products and wastes between crop production and livestock production. These methods are capable of increasing feed resources availability during the dry season and also replenish the soil for crop production through the use of faecal wastes from livestock. The major engagement of agro-pastoralists in Nigeria involves CLIS in a way though biomass inputs and outputs recycling are not scientifically calculated by the farmers (Iyiola-Tunji et al., 2017).

Breeding for more productive animals Breeding for more productive animals was suggested by $50 \%$ of the respondents as an adaptive measure for reduction of 


\section{Iyiola-Tunji}

greenhouse gas emissions. Selective breeding that is aimed at improving production efficiencies had been reported to result into increase productivity and gross efficiency by optimize the cost of production and reduce the number of animals that are needed to produce the same quantity of products (Bell et al., 2012). Reports from van de Haar and St. Pierr (2006) and Chagunda et al. (2009) related that more energy efficient animals produce less waste in the form of methane and nitrogen excretion per unit product. The path towards reduced emission of greenhouse gases through selective breeding was depicted in Figure 1. Animals that are selectively bred to utilize low inputs and give high outputs are expected to produce milk and meat (as the case may be) efficiently. The quantity of GHG emissions will be reduced once the number of animals put into productive use are reduced.

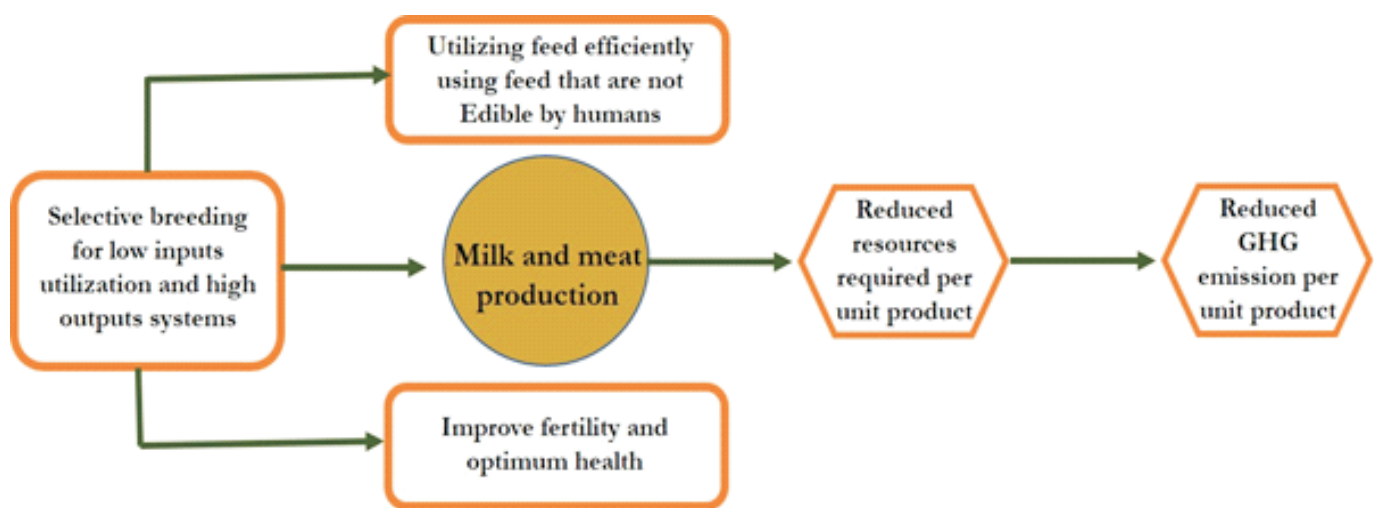

Figure 1: Production efficiencies using management that can reduce GHG emissions beginning with selective breeding of a genotype for a particular system (adapted from Bell (2011); modified by Iyiola-Tunji, A.O. (2021)

\section{Use of methane reducing feed additives}

The use of methane reducing feed additives was stated by $26.4 \%$ of the respondents as being capable of reducing the effect of livestock production activities on GHG emissions. Kataria (2015) observed that the practice of using feed additives to mitigate enteric methane production is more prominent in developed countries of the world where ruminant livestock are kept in well managed production systems and generally fed diets that are very high in digestibility and nutrients. The results of this practice according to the author are an efficient production (milk or meat) relative to the amount of methane emitted. Klop (2016) expressed the advantage of using feed additives to mitigate GHG emissions as they are supplied in such amounts that the basal diet composition will not be largely affected by the feed additives (Klop, 2016). Methane-reducing feed additives and supplements inhibit methanogens in the rumen, and subsequently reduce enteric methane emissions (Curnow, 2019). Methane-reducing feed additives and supplements can be synthetic chemicals, natural supplements and compounds, such as tannins and seaweed fats and oils. (Curnow, 2019). van Zijderveld et al. (2010) had experimented with lauric acid, myristic acid, linseed oil and calcium fumarate as additives and obtained favourable results in the reduction of GHG emissions. Sunflower oil and monensin offer the greatest reductions in methane without substantial reductions in diet digestibility (Beauchemin and McGinn 
(2016). It is of note that the practice of using feed additives as an adaptive measure to reduce GHG emissions in developing countries like Nigeria is almost nonexistent.

\section{Ranching}

To further reduce livestock's greenhouse gas emissions while continuing to provide meat for a growing world population, beef cattle ranchers are proactively implementing methane-reducing methods to manage manure, improve soil health, and enhance herd efficiency. Ranching will enable farmers to consciously engage in practices that are capable of mitigating the effect of climate change on their livestock and also make attempt at GHG emissions from their livestock.

\section{Pathway of responses based on Nigerian farmers' suggested adaptations to climate change}

The dual pathways of responses between climate change and livestock production activities were depicted on Figure 2. Activities from livestock have very high tendencies to impact negatively on the environment and eventually causing unfavorable variability of climate and its elements. That was indicated in the blue big (fat) arrow that goes away from livestock to the environment and climate. The major component of the activities of livestock that was known to cause injury to the environment as depicted in Figure 2 is the production of greenhouse gases (shown in an orange box on the right-hand side of the pathway). From the respondents in this study, some adaptive measures were stated as having controlling and mitigating effect at reducing the effect of activities of livestock on the climate and the environment. When these measures such as planting of trees to absorb $\mathrm{CO}_{2}$, adequate waste management and utilization, feeding of livestock with methane reducing feed additives and breeding of animals with faster growth rate are effectively deployed, the destruction of the environment will be reduced. Key breeding traits associated with climate change resilience and adaptation includes thermal tolerance, low quality feed, high survival rate, disease resistance, good body condition and animal morphology (Hoffman, 2008; Oseni and Bebe, 2010). In general, developing countries have a weak capacity for hightech breeding programmes towards livestock improvement (IFAD, 2002). Therefore, programmes based on controlled mating methods are likely to be more appropriate. These programmes usually do not produce immediate improvements. Improvements are usually not seen for at least one growing season, so a livestock producer must be able to incorporate longterm planning into production management strategies. Such measures could include: identifying and strengthening local breeds that have adapted to local climatic stress and feed sources and improving local genetics through cross-breeding with heat and disease tolerant breeds.

The environment and climate on the other side of the dual pathway is also known to induce stress on livestock. The respondents in this study stated that the components of the pathway that are in yellow boxes are capable of limiting the stress caused by high variations of climatic elements. The concept of crop-livestock integration system is advocated in this study as beneficial to livestock and environment in the short and long run. 


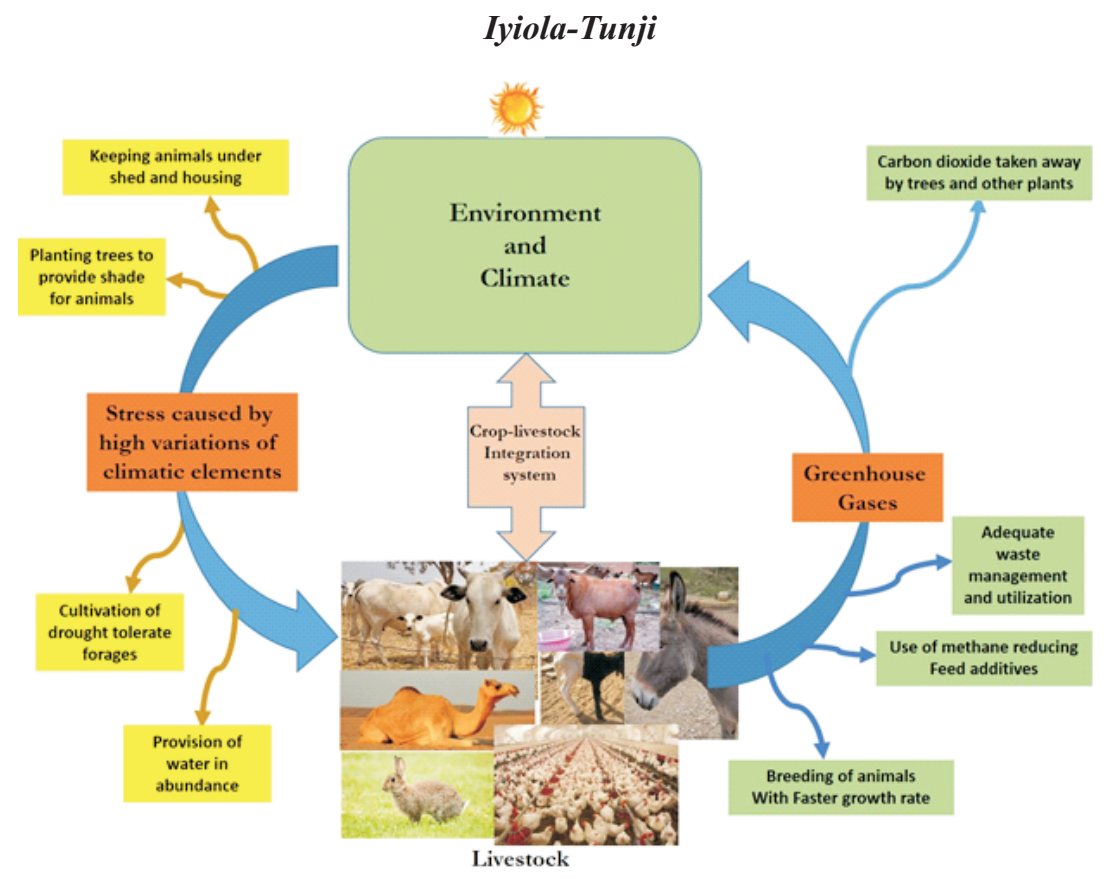

\section{Figure 2: Dual pathways of responses between climate change and livestock production}

Strategies for Climate-Smart Livestock Production in Nigeria

The following have been identified as key elements that should be taken into account to support the design of development interventions for climate-smart livestock production in Nigeria:

Collaborative management of natural resources: participatory approaches to sustainable management of land, forest and natural resources (NRM) are essential to develop long-term sustainable strategies. Decision making processes should be designed in order to include all concerned stakeholders (farmers, pastoralists, herders etc).

Community involvement in adaptation strategies: successful adaptation strategies cannot be developed in isolation. Community involvement in the identification of new solutions is key to ensure the long-term sustainability of interventions. At the same time, adaptation strategies need to be developed taking into account cross-cutting issues (i.e. environment, health and social such as increased migration, conflict).

Incentives and tailored responses: financial incentives and regulations for improving natural resource management and livestock production systems through proper pasture/land management and feeding management can be used as incentives to encourage GHG mitigation and adaptation. Indeed, the introduction of tailored indexbased insurance schemes and rural finance initiatives are the keys to support livestock keepers better cope with climate change risks.

Subsidies: when including subsidies or other enticements in development activities, careful attention will need to be given to their effects. While in some instances they could support adaptation strategies (i.e. promoting the introduction of heat-resistant breeds, subsidizing vaccinations to reduce vulnerability to the spread of new diseases) in others subsidies could negatively a f f e c t adaptation/mitigation strategies.

Risk management mechanisms: proper risk management mechanisms and preparedness 


\section{Climate-smart livestock production: options for Nigerian farmers}

measures will need to be put in place to cope with the impacts of more frequent and extreme climatic events. Preparedness measures, early warning systems and other risk mitigation activities (i.e. strengthening infrastructures, insurance systems, forecasting, etc) will be needed to reduce impacts of severe weather events to prevent loss of livestock.

Awareness and education: information on climate change is a crucial component of adaptation and efforts should be made to ensure that knowledge is shared with local communities. Understanding the patterns of variability of current and projected climate and seasonal forecasts is crucial to anticipate shock and losses and to enable external agencies to provide targeted assistance to herders.

Mitigation: to support mitigation of GHG emissions efforts should focus on reforestation, improved grazing management, restoration of degraded lands, livestock manure management, improved feeding management, improved energy/feed efficiency, selection of more productive animal breeds and transhumance practices.

Innovation, Research and Technology development: promoting the development of and improved access to technologies, and sharing knowledge on sustainable and climate-friendly farming practices is vital. Country specific research is needed to inform the development of adaptive strategies and more focus needs to be given to 'the development of improved crop varieties and animal breeds, as well as more sustainable and integrated management of crops, animals and the natural resource base that sustain their production, while providing other vital services for people and the environment' (IFAD, 2009) to increase resilience of developing countries.

Gender dimension: adaptation and mitigation strategies should take into account the different roles of women and men and the way in which they will be impacted by climate change. Climate change clearly offers an opportunity to rethink gender inequities and to involve both women and men in finding innovative solutions that can respond to common environmental challenges.

Indigenous knowledge: the in-depth understanding of the environments that local communities and indigenous peoples have, together with their experience in adapting to climate variability are key for development of adaptation and mitigation strategies.

\section{Conclusion}

The actions and in-actions of man will dictate the type of results obtainable in his immediate environment. Concerted efforts at ameliorating the effect of climate change on livestock production are needed. The smart options for rearing livestock are capable of mitigating the attendant effect of production activities of the stocks, reducing the stress obtainable from altered environment and ensuring food security. Nigeria as a country will need to evolve policies that will ensure promotion and subsequent adoptions of technologies that are smart in terms of increasing productivity of farm animals, reducing emissions of GHG and positively altering the effect of climate change.

\section{References}

Abdela, N. and Jilo, K. 2016. Impact of climate change on livestock health: a review. Global Veterinaria, 16(5): 419-424.

Aydinalp, C. and Cresser, M. S. 2008. The effects of global climate change on agriculture. American-Eurasian Journal of Agricultural and Environmental Science, 3: 672-676.

Batima, P., Bat, B., Tserendash, L., Bayarbaatar, S., Shiirev-Adya, S. Tuvaansuren, G., Natsagdorj, L. 
and Chuluun, T. 2005. Adaptation to Climate Change, Vol. 90, ADMON Publishing, Ulaanbaatar.

Baylis, M. and Githeko, A. K. 2006. The effects of climate change on infectious diseases of animals. Report for the Foresight Project on Detection of Infectious Diseases, Department of Trade and Industry, UK Government.

Beauchemin, K. A. and McGinn, S. M. 2006. Effects of various feed additives on the methane emissions from beef cattle.International Congress Series, 1293: 152-155.

https://doi.org/10.1016/j.ics.2006.01.042

Bell, M. J., Eckard, R. J. and Pryce, J. E. 2012. Breeding Dairy Cows to Reduce Greenhouse Gas Emissions, Livestock Production, Khalid Javed, IntechOpen, DOI: 10.5772/50395. A v a i 1 a ble f r o m : https://www.intechopen.com/books /livestock-production/breedingdairy-cows-to-reduce-greenhousegas-emissions (Accessed on $25^{\text {th }}$ September, 2020).

Chagunda, M. G. G., Römer, D. A. M. and Roberts, D. J. 2009. Effect of genotype and feeding regime on enteric methane, non-milk nitrogen and performance of dairy cows during the winter feeding period. Livestock Science, 122: 323-332.

Curnow, M. 2019. Carbon farming: reducing methane emissions from cattle using feed additives. https://www.agric.wa.gov.au/climat e-change/carbon-farming-reducingmethane-emissions-cattle-usingfeed-additives (Accessed on 25th September, 2020).

Dickie, A., Streck, C., Roe, S., Zurek, M., Haupt, F. and Dolginow, A. 2014. Strategies for mitigating climate change in agriculture: Abridged report. Climate focus and california environmental associates, prifadred with the support of the climate and land use Alliance. Report and supplementary materials available a $\mathrm{t}$ : $<$ www.agriculturalmitigation.org $>$.

FAO 2006. Livestock's long shadow: environmental issues and options. Rome.

FAO 2009. Carbon sequestration in grasslands: technical, economic and policy issues. Draft

briefing paper. FAO, Rome.

FAO 2012. Livestock sector development for poverty reduction: an economic and policy perspective - Livestock's many virtues, by J. Otte, A. Costales, J. Dijkman, U. Pica-Ciamarra, T. Robinson, V. Ahuja, C. Ly and D. Roland-Holst. Rome, pp. 161.

Harle, K. J., Howden, S. M., Hunt, L. P., Dunlop, M. 2007. The potential impact of climate change on the Australian wool industry by 2030 . Agricultural Systems 93: 61-89. doi:10.1016/j.agsy.2006.04.003

Henry, B., Charmley, E., Eckard, Gaughan, R. J. B, Hegarty, R. 2012. Livestock production in a changing climate: adaptation and mitigation research in Australia Crop Pasture Science, 63: 191-202.

Hess, H. D., Tiemann, T. T., Noto, F., Carulla, J. E. and Kreuzer, M. 2006. Strategic use of tannins as means to limit methane emission from ruminant livestock. International Conference on Greenhouse Gases and Animal Agriculture, Elsevier International Congress Series, Zurich, Switzerland, 129: 164-167.

Hoffmann, I. 2008. Livestock Genetic Diversity and Climate Change Adaptation. Livestock and Global Change conference proceeding. May 2008, Tunisia

Hoffman, M. and Vogel, C. 2008. 'Climate change impacts on African 
rangelands', Rangelands, 30: 12-17.

Ickowicz, A., Ancey, V., Corniaux, C., Duteurtre, G., Poccard-Chappuis, R., Touré, I., Vall, E. and Wane, A. 2012. Crop-livestock production systems in the Sahel- increasing resilience for adaptation to climate change and preserving food security. Building resilience for adaptation to climate change in the agriculture sector. Proceedings of a Joint FAO/OECD Workshop. Edited by Alexandre Meybeck, Jussi Lankoski, Suzanne Redfern,Nadine Azzu and Vincent Gitz.

http://www.fao.org/3/i3084e/i3084e.pdf

IFAD (The International Fund for Agricultural Development) 2002. 'The Rural Poor' in World Poverty Report, IFAD, Rome.

IFAD, 2009. (Draft) Comprehensive Report on IFAD's Response to Climate Change Through Support to Adaptation and Related Actions

IFAD (International Fund for Agricultural Development) 2010. Livestock and climate change. http://www.ifad.org/lrkm/events/co ps/papers/climate.pdf

Iyiola-Tunji A. O., Adamu J. I., John P.

A., Muniru, I. 2021. Dual Pathway Model of Responses Between Climate Change and Livestock Production. In: Leal Filho W., Ogugu N., Adelake L., Ayal D., da Silva I. (eds) African Handbook of Climate Change Adaptation. $\mathrm{S}$ p r i n g e r, C h a m . https://doi.org/10.1007/978-3-03042091-8 230-1

Iyiola-Tunji, A. O., Annatte, I., Adesina, M.A., Ojo, O. A., Buba, W., Nuhu, S., Bello, M., Saleh, I., Yusuf, A. M., Tukur, A. M., Hussaini, A. T., and Aguiri, A. O. (2015). Evaluation of Crop-Livestock Integration Systems among Rural Farm Families at Adopted Villages of National Agricultural Extension and Research Liaison Services. Journal of Agricultural Extension, 19(2): 46-58.

Kataria, R. P. 2015. Use of feed additives for reducing greenhouse gas emissions from dairy farms. Microbiology Research, 6(6120): 19-25.

Klop, G. 2016. Low Emission Feed - Using feed additives to decrease methane production in dairy cows. Ph.D thesis, Wageningen University, Wageningen, NL. 168 pages. ISBN 978-94-6257-894-4. DO I $10.18174 / 387944$

Kurukulasuriya, P. and Rosenthal, S. 2003. Climate change and agriculture: a review of impacts and adaptations. Climate Change Series Paper No. 91, World Bank, Washington DC.

Lamidi, O.S. 2005. The use of some nonconventional protein sources for fattening cattle. Unpublished Ph.D Thesis submitted to the School of Post Graduate Studies, Ahmadu Bello University, Zaria.

Lindgren, J. 2019. Reducing Greenhouse Gas Emissions from Cattle Production. Friday, October 4, 2019. https://water.unl.edu/article/animalmanure-management/reducinggreenhouse-gas-emissions-cattleproduction

Misra, A. K, 2005. Contingency planning for feeding and management of livestock during drought. In: K D Sharma and K S Ramasastri (Editors) Drought Management. Allied Publishers Pvt. Ltd., New Delhi.

Oseni, S. and Bebe, O. 2008. Climate change, genetics of adaptation and livestock production in low-input systems, paper presented at ICID +18 2nd International Conference: Climate, Sustainability 
and Development in Semi-Arid Regions August 16 - 20, 2010, Fortaleza - Ceará, Brazil and Hoffmann, I. 2008. Livestock Genetic Diversity and Climate Change Adaptation. Livestock and Global Change conference proceeding. May 2008, Tunisia.

Pasha, S. M. 2000. Economy and ecological dimensions of livestock economy. Commonwealth publishers, New Delhi.

Pollot, G. and Wilson, R. T. 2009. Sheep and Goats for diverse products and profits (FAO Rome) In: FAO Diversification Booklet (FAO), no. 9 / FAO, Rome (Italy). Rural Infrastructure and Agro-Industries Div, 2009, 42.

Revi, A., Satterthwaite, D.E., AragónDurand, F. Corfee-Morlot, J., Kiunsi, R.B.R., Pelling, M., Roberts, D.C. and Solecki, W, 2014. Urban areas Climate Change 2014: Impacts, Adaptation, and Vulnerability. Part A: Global and Sectoral Aspects. In: Contribution of Working Group II to the Fifth Assessment Report of the Intergovernmental Panel on Climate Change [Field, C.B., Barros, V.R., Dokken, D.J. (eds.)]. Cambridge University Press, New York, NY, USA, 535-612.

Rowlinson, P., Steele, M. and Nefzaoui, A. 2008. Livestock and global climate change: Adaptation I and II. In: Rowlinson, P., Steel, M., Nefzaoui, A. (Eds.), Livestock and Global Climate Change Conference Proceeding. Cambridge University Press, Tunisia, pp. 56-85.

Steinfeld, H. 2006. Livestock's Long Shadow: Environmental Issues and Options, FAO, Rome, Italy.

Thornton, P. 2010. 'Livestock production: recent trends, future prospects,
Philosophical Transactions of the Royal Society B, 365: 2853-2867.

Thornton P., Herrero M., Freeman A., Mwai O., Rege E., Jones P., and McDermott J. 2008. "Vulnerability, Climate change and Livestock Research Opportunities and Challenges for Poverty Alleviation". ILRI, Kenya.

Van der Peet-Schwering, C. M. C., Aarnink, A. J. A., Rom, H. B. and Dourmad, J. Y. 1999. Ammonia emissions from pig houses in the Netherlands, Denmark and France. Livestock Production Science, 58: 265-269.

Van der Sluis, W. 2007. Intensive Poultry Production. World's Poultry Science Journal, 23: 28-30.

Van der Werf H, M. G., Petit, J. and S a nd e rs, J . 2005 . Th e environmental impacts of the production of concentrated feed: the case of pig feed in Bretagne. Agricultural System 83: 153-177.

van Zijderveld, S. M., Fonken, B., Dijkstra, J., Gerrits, W. J. J., Perdok, H.B., Fokkink, W. and Newbold, J. R. 2010. Effects of a combination of feed additives on methane production, diet digestibility, and animal performance in lactating da] iiry cows. Journal of Dairy Science, 94: 1445-1454. doi: 10.3168/jds.20103635 .

Williams, A. G., Audsley, E., Sandars, D. L. 2006. Determining the Environmental Burdens and Resource Use in the Production of Agricultural and Horticultural Commodities. Natural Resource Management Institute, Cranfield University, Silsoe Research Institute, Bedford.

Received: $18^{\text {th }}$ Noveember, 2020 Accepted: $15^{\text {th }}$ February, 2021 